\title{
Transient Temperature Safety Testing of AGR-2 UCO Compacts 5-1-1, 5-1-2, and 5-1-3
}

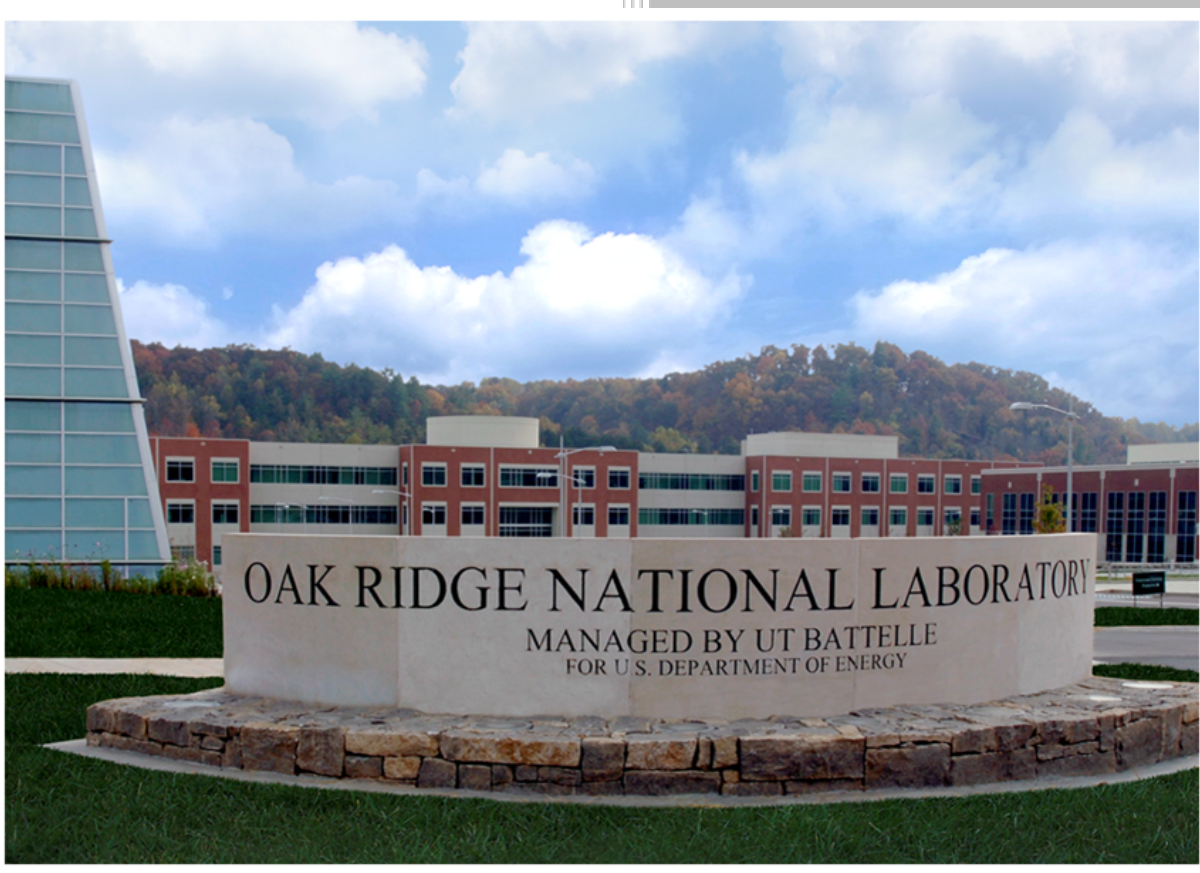

\section{Approved for public release.}

Distribution is unlimited.

John D. Hunn

Robert N. Morris

Zachary M. Burns

September 2019 


\title{
DOCUMENT AVAILABILITY
}

Reports produced after January 1, 1996, are generally available free via US Department of Energy (DOE) SciTech Connect.

Website www.osti.gov

Reports produced before January 1, 1996, may be purchased by members of the public from the following source:

\author{
National Technical Information Service \\ 5285 Port Royal Road \\ Springfield, VA 22161 \\ Telephone 703-605-6000 (1-800-553-6847) \\ TDD 703-487-4639 \\ Fax 703-605-6900 \\ E-mail info@ntis.gov \\ Website http://classic.ntis.gov/
}

Reports are available to DOE employees, DOE contractors, Energy Technology Data Exchange representatives, and International Nuclear Information System representatives from the following source:

Office of Scientific and Technical Information

PO Box 62

Oak Ridge, TN 37831

Telephone 865-576-8401

Fax 865-576-5728

E-mail reports@osti.gov

Website http://www.osti.gov/contact.html

This report was prepared as an account of work sponsored by an agency of the United States Government. Neither the United States Government nor any agency thereof, nor any of their employees, makes any warranty, express or implied, or assumes any legal liability or responsibility for the accuracy, completeness, or usefulness of any information, apparatus, product, or process disclosed, or represents that its use would not infringe privately owned rights. Reference herein to any specific commercial product, process, or service by trade name, trademark, manufacturer, or otherwise, does not necessarily constitute or imply its endorsement, recommendation, or favoring by the United States Government or any agency thereof. The views and opinions of authors expressed herein do not necessarily state or reflect those of the United States Government or any agency thereof. 
Reactor and Nuclear Systems Division

\title{
TRANSIENT TEMPERATURE SAFETY TESTING OF AGR-2 UCO COMPACTS 5-1-1, 5-1-2, AND 5-3-1
}

\author{
John D. Hunn \\ Robert N. Morris \\ Zachary M. Burns
}

Revision 0

Date Published: September 2019

\author{
Work sponsored by \\ US DEPARTMENT OF ENERGY \\ Office of Nuclear Energy - Advanced Reactor Technologies \\ under the
}

Advanced Gas Reactor Fuel Development and Qualification Program

Prepared by OAK RIDGE NATIONAL LABORATORY

Oak Ridge, TN 37831-6283

managed by

UT-BATTELLE, LLC

for the

US DEPARTMENT OF ENERGY

under contract DE-AC05-00OR22725 



\section{CONTENTS}

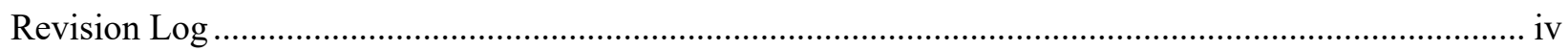

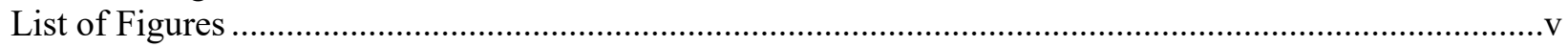

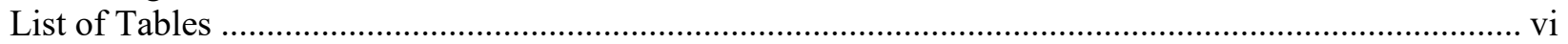

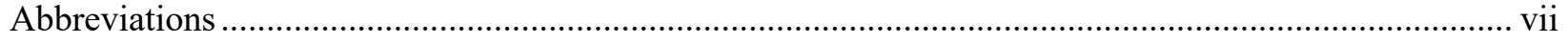

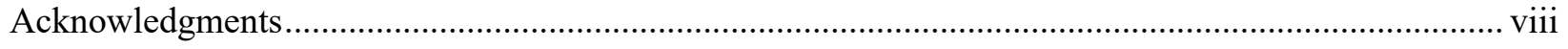

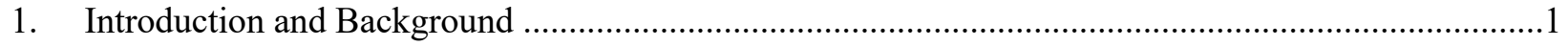

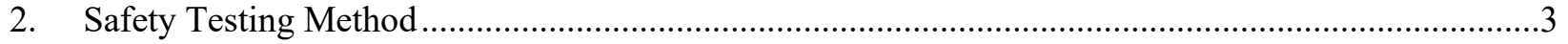

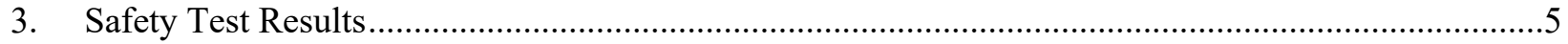

$3.1 \quad$ Silver Release During Safety Testing …………………………………………………....6

3.2 Krypton and Cesium Release During Safety Testing …………..............................................

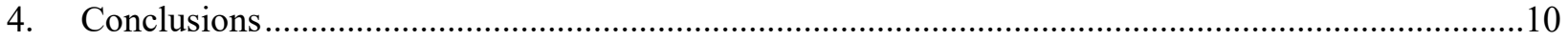

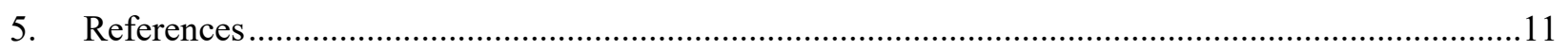




\section{REVISION LOG}

\begin{tabular}{llll}
\hline Revision & Date & Affected Pages & Revision Description \\
\hline 0 & & All & Initial issue
\end{tabular}




\section{LIST OF FIGURES}

2-1. CCCTF graphite holders: (a) one-compact holder, (b) three-compact holder with dimensions, and (c) three-compact holder.

2-2. Transient temperature profile used for safety testing of Compacts $5-1-1,5-1-2$, and $5-3-1 \ldots \ldots \ldots \ldots \ldots . .4$

3-1. Fractional release during the transient temperature safety test (1E-4 is equivalent to the

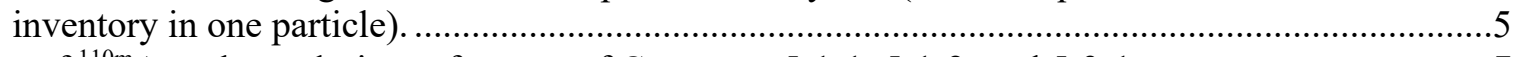

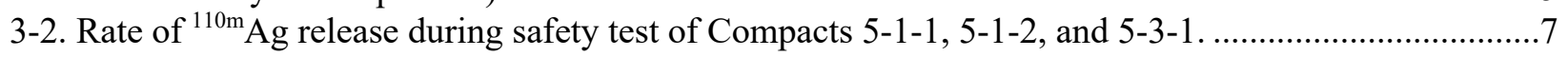

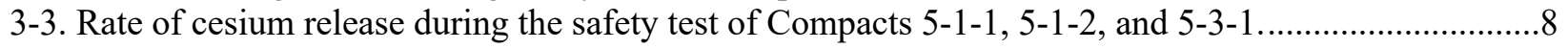




\section{LIST OF TABLES}

1-1. US AGR-2 compacts subjected to isothermal safety testing .........................................................

1-2. Irradiation conditions for US AGR-2 compacts subjected to transient temperature safety testing ........2

2-1. Temperature setpoints used for safety testing of Compacts 5-1-1, 5-1-2, and 5-3-1 .......................4

3-1. Activities and average collection efficiencies for silver and cesium ..............................................6

3-2. Minor release of ${ }^{85} \mathrm{Kr}$ and ${ }^{134} \mathrm{Cs}$ from AGR-2 UCO compacts with no failed particles ....................... 


\section{ABBREVIATIONS}

AGR Advanced Gas Reactor (Fuel Development and Qualification Program)

AGR-1 first AGR program irradiation experiment

AGR-2 second AGR program irradiation experiment

AVR

CCCTF

$\mathrm{CO}$

DLBL

FIMA

INL

OPyC

ORNL

PIE

$\mathrm{SiC}$

Arbeitsgemeinschaft Versuchsreaktor (an experimental reactor in Germany)

Core Conduction Cooldown Test Facility

carbon monoxide

deconsolidation and leach-burn-leach

fissions per initial metal atom

Idaho National Laboratory

outer pyrolytic carbon (TRISO layer)

Oak Ridge National Laboratory

post-irradiation examination

$\mathrm{TA}_{\max }$

$\mathrm{TA}_{\min }$

silicon carbide (TRISO layer)

time-average maximum (temperature)

TAVA

time-average minimum (temperature)

TRISO

time-average, volume-average (temperature)

$\mathrm{UCO}$

tristructural-isotropic (coated particles)

$\mathrm{UO}_{2}$

uranium carbide/uranium oxide mixture (fuel kernels)

uranium dioxide (fuel kernels) 


\section{ACKNOWLEDGMENTS}

This work was sponsored by the US Department of Energy's Office of Nuclear Energy through the Idaho National Laboratory Advanced Reactor Technologies as part of the Advanced Gas Reactor Fuel Development and Qualification Program. Hot cell activities were supported by the staff of the Oak Ridge National Laboratory Irradiated Fuels Examination Laboratory. 


\section{INTRODUCTION AND BACKGROUND}

Post-irradiation examination (PIE) and elevated-temperature safety testing are being performed on tristructural-isotropic (TRISO) coated-particle fuel compacts from the Advanced Gas Reactor (AGR) Fuel Development and Qualification Program's second irradiation experiment (AGR-2). Previous reports provide background information on (1) the fuel fabrication (Barnes and Marshall 2009; Hunn, Montgomery, and Pappano 2010a; Hunn, Montgomery, and Pappano 2010b), (2) the as-fabricated fuel properties (Hunn 2010; Hunn, Savage, and Silva 2010), (3) the irradiation experiment (Collin 2014), and (4) the comprehensive PIE plan (Demkowicz 2013).

Fifteen isothermal safety tests have been completed in the Oak Ridge National Laboratory (ORNL) Core Conduction Cooldown Test Facility (CCCTF) on US AGR-2 compacts, where the TRISO particle kernels were either made of uranium dioxide $\left(\mathrm{UO}_{2}\right)$ or made up of a mixture of uranium carbide and uranium oxide (UCO). In the UCO kernel design, uranium carbide is included to limit carbon monoxide (CO) production by gettering oxygen liberated from the $\mathrm{UO}_{2}$ during fission. Table 1-1 lists the calculated average burnup in percent fissions per initial metal atom (FIMA), the fast neutron fluence (neutron energies $>0.18 \mathrm{MeV}$ ), and the average compact temperatures during irradiation. Results of these tests are available in the summary reports listed in the table.

Table 1-1. US AGR-2 compacts subjected to isothermal safety testing

\begin{tabular}{|c|c|c|c|c|c|c|c|c|}
\hline \multirow{2}{*}{$\begin{array}{l}\text { AGR-2 } \\
\text { Compact }^{a}\end{array}$} & \multirow{2}{*}{$\begin{array}{l}\text { Kernel } \\
\text { type }\end{array}$} & \multirow{2}{*}{$\begin{array}{l}\text { Safety test } \\
\text { temperature }\end{array}$} & \multirow{2}{*}{$\begin{array}{l}\text { Burnup }^{b} \\
\text { (FIMA) }\end{array}$} & \multirow{2}{*}{$\begin{array}{l}\text { Fast fluence }^{b} \\
(\mathrm{E}>0.18 \mathrm{MeV})\end{array}$} & \multicolumn{3}{|c|}{ Irradiation temperature $^{c}$} & \multirow{2}{*}{$\begin{array}{c}\text { Safety test } \\
\text { summary report }^{d}\end{array}$} \\
\hline & & & & & TAVA & $\mathrm{TA}_{\min }$ & $\mathrm{TA}_{\max }$ & \\
\hline $3-3-2$ & $\mathrm{UO}_{2}$ & $1,600^{\circ} \mathrm{C}$ & $10.54 \%$ & $3.53 \times 10^{25} \mathrm{n} / \mathrm{m}^{2}$ & $1,062^{\circ} \mathrm{C}$ & $999^{\circ} \mathrm{C}$ & $1,105^{\circ} \mathrm{C}$ & Hunn et al. 2015a \\
\hline $3-4-1$ & $\mathrm{UO}_{2}$ & $1,700^{\circ} \mathrm{C}$ & $10.62 \%$ & $3.47 \times 10^{25} \mathrm{n} / \mathrm{m}^{2}$ & $1,013^{\circ} \mathrm{C}$ & $901^{\circ} \mathrm{C}$ & $1,085^{\circ} \mathrm{C}$ & Hunn et al. 2018a \\
\hline $3-4-2$ & $\mathrm{UO}_{2}$ & $1,600^{\circ} \mathrm{C}$ & $10.69 \%$ & $3.50 \times 10^{25} \mathrm{n} / \mathrm{m}^{2}$ & $1,013^{\circ} \mathrm{C}$ & $904^{\circ} \mathrm{C}$ & $1,085^{\circ} \mathrm{C}$ & Hunn et al. $2015 \mathrm{a}$ \\
\hline $3-1-1$ & $\mathrm{UO}_{2}$ & $1,500^{\circ} \mathrm{C}$ & $10.60 \%$ & $3.41 \times 10^{25} \mathrm{n} / \mathrm{m}^{2}$ & $1,011^{\circ} \mathrm{C}$ & $900^{\circ} \mathrm{C}$ & $1,083^{\circ} \mathrm{C}$ & $d$ \\
\hline $2-1-2$ & $\mathrm{UCO}$ & $1800^{\circ} \mathrm{C}$ & $12.62 \%$ & $3.25 \times 10^{25} \mathrm{n} / \mathrm{m}^{2}$ & $1,219^{\circ} \mathrm{C}$ & $1,055^{\circ} \mathrm{C}$ & $1,324^{\circ} \mathrm{C}$ & Hunn et al. 2019a \\
\hline $2-2-2$ & $\mathrm{UCO}$ & $1,600^{\circ} \mathrm{C}$ & $12.55 \%$ & $3.39 \times 10^{25} \mathrm{n} / \mathrm{m}^{2}$ & $1,287^{\circ} \mathrm{C}$ & $1,189^{\circ} \mathrm{C}$ & $1,354^{\circ} \mathrm{C}$ & Hunn et al. 2016 \\
\hline $2-3-1$ & $\mathrm{UCO}$ & $1,600^{\circ} \mathrm{C}$ & $12.63 \%$ & $3.42 \times 10^{25} \mathrm{n} / \mathrm{m}^{2}$ & $1,296^{\circ} \mathrm{C}$ & $1,195^{\circ} \mathrm{C}$ & $1,360^{\circ} \mathrm{C}$ & Hunn et al. 2017 \\
\hline $2-3-2$ & $\mathrm{UCO}$ & $1,800^{\circ} \mathrm{C}$ & $12.68 \%$ & $3.46 \times 10^{25} \mathrm{n} / \mathrm{m}^{2}$ & $1,296^{\circ} \mathrm{C}$ & $1,199^{\circ} \mathrm{C}$ & $1,360^{\circ} \mathrm{C}$ & Hunn et al. $2018 \mathrm{a}$ \\
\hline $5-2-1$ & $\mathrm{UCO}$ & $1,600^{\circ} \mathrm{C}$ & $12.28 \%$ & $3.38 \times 10^{25} \mathrm{n} / \mathrm{m}^{2}$ & $1,141^{\circ} \mathrm{C}$ & $1,032^{\circ} \mathrm{C}$ & $1,209^{\circ} \mathrm{C}$ & $d$ \\
\hline $5-2-2$ & $\mathrm{UCO}$ & $1,600^{\circ} \mathrm{C}$ & $12.34 \%$ & $3.39 \times 10^{25} \mathrm{n} / \mathrm{m}^{2}$ & $1,141^{\circ} \mathrm{C}$ & $1,037^{\circ} \mathrm{C}$ & $1,210^{\circ} \mathrm{C}$ & Hunn et al. 2016 \\
\hline $5-4-1$ & $\mathrm{UCO}$ & $1,800^{\circ} \mathrm{C}$ & $12.05 \%$ & $3.12 \times 10^{25} \mathrm{n} / \mathrm{m}^{2}$ & $1,071^{\circ} \mathrm{C}$ & $923^{\circ} \mathrm{C}$ & $1,168^{\circ} \mathrm{C}$ & Hunn et al. 2016 \\
\hline $6-2-1$ & $\mathrm{UCO}$ & $1,800^{\circ} \mathrm{C}$ & $10.16 \%$ & $2.60 \times 10^{25} \mathrm{n} / \mathrm{m}^{2}$ & $1,129^{\circ} \mathrm{C}$ & $1,044^{\circ} \mathrm{C}$ & $1,183^{\circ} \mathrm{C}$ & $d$ \\
\hline $6-2-2$ & $\mathrm{UCO}$ & $1,600^{\circ} \mathrm{C}$ & $10.19 \%$ & $2.61 \times 10^{25} \mathrm{n} / \mathrm{m}^{2}$ & $1,129^{\circ} \mathrm{C}$ & $1,047^{\circ} \mathrm{C}$ & $1,183^{\circ} \mathrm{C}$ & $d$ \\
\hline $6-4-2$ & $\mathrm{UCO}$ & $1,600^{\circ} \mathrm{C}$ & $9.26 \%$ & $2.21 \times 10^{25} \mathrm{n} / \mathrm{m}^{2}$ & $1,018^{\circ} \mathrm{C}$ & $894^{\circ} \mathrm{C}$ & $1,106^{\circ} \mathrm{C}$ & Hunn et al. 2017 \\
\hline $6-4-3$ & UCO & $1,800^{\circ} \mathrm{C}$ & $7.26 \%$ & $1.94 \times 10^{25} \mathrm{n} / \mathrm{m}^{2}$ & $987^{\circ} \mathrm{C}$ & $868^{\circ} \mathrm{C}$ & $1,080^{\circ} \mathrm{C}$ & Hunn et al. $2019 b$ \\
\hline
\end{tabular}

${ }^{a}$ The X-Y-Z compact numbering convention denotes the compact's location in the irradiation test train: capsule-level-stack.

${ }^{b}$ Burnup (Sterbentz 2014, Table 6) and fast fluence (Sterbentz 2014, Table 12) are based on physics calculations.

${ }^{c}$ Time-average, volume-average (TAVA) temperature, time-average minimum (TAmin) temperature, and time-average maximum (TAmax) temperature are based on thermal calculations (Hawkes 2014, Table 3).

${ }^{d}$ Summary reports for these compacts will be issued in fiscal year 2020.

Compacts with UCO kernels were heated for $300 \mathrm{~h}$ at maximum temperatures of either $1,600^{\circ} \mathrm{C}$ or $1,800^{\circ} \mathrm{C}$. A safety test temperature of $1,600^{\circ} \mathrm{C}$ was chosen because it is the maximum temperature expected during a depressurization conduction-cooldown event in a typical high-temperature gas-cooled reactor. The higher test temperature of $1,800^{\circ} \mathrm{C}$ was used to explore the safety margin and provide additional data on mechanisms for particle coating failure, fission product and actinide diffusion, and 
other fission product and actinide interactions with the TRISO coatings. No UCO-TRISO particles exhibited elevated release from coating failure at $1,600^{\circ} \mathrm{C}$, while UCO-compacts safety tested at $1,800^{\circ} \mathrm{C}$ exhibited cesium release from 0-2 particles with degraded silicon carbide (SiC) layers.

Compacts with $\mathrm{UO}_{2}$ kernels were also safety tested for $300 \mathrm{~h}$ at $1,600^{\circ} \mathrm{C}$, and these compacts exhibited significantly higher failure fractions compared with the UCO fuel because of CO corrosion (Hunn et al. 2018b). Compacts with $\mathrm{UO}_{2}$ kernels were not tested at $1,800^{\circ} \mathrm{C}$ because fission product release at this temperature was expected to exceed CCCTF operational limits. One $\mathrm{UO}_{2}$ compact margin test was conducted at $1,700^{\circ} \mathrm{C}$ but had to be terminated after $162 \mathrm{~h}$ at $1,700^{\circ} \mathrm{C}$ because the radiological dose rate from fission product release was approaching operational limits. One $\mathrm{UO}_{2}$ compact was tested at $1,500^{\circ} \mathrm{C}$, and this lower temperature reduced the $\mathrm{CO}$ corrosion rate such that cesium release fractions were similar to the UCO compacts tested at $1,800^{\circ} \mathrm{C}$.

Reported herein are the initial results obtained from a transient temperature safety test performed on the three AGR-2 UCO compacts listed in Table 1-2. The compacts were heated simultaneously in the CCCTF in flowing helium to a peak temperature of $1,695^{\circ} \mathrm{C}$ using the transient temperature profile discussed in Section 2. During the test, the activity from ${ }^{85} \mathrm{Kr}$ was monitored on the liquid-nitrogen-cooled sweep gas traps to determine whether any particles experienced failure of the gas retention performance of the TRISO coating. In addition, ${ }^{134} \mathrm{Cs}$ and ${ }^{137} \mathrm{Cs}$, which can diffuse through an intact, gas-tight pyrocarbon layer, were collected on water-cooled deposition cups to determine whether any particles experienced significant degradation or failure of the $\mathrm{SiC}$ layer's ability to retain fission products.

Table 1-2. Irradiation conditions for US AGR-2 compacts subjected to transient temperature safety testing

\begin{tabular}{|c|c|c|c|c|c|c|c|}
\hline \multirow{2}{*}{$\begin{array}{l}\text { AGR-2 } \\
\text { Compact }^{a}\end{array}$} & \multirow{2}{*}{$\begin{array}{l}\text { Kernel } \\
\text { type }\end{array}$} & \multirow{2}{*}{$\begin{array}{l}\text { Fabrication } \\
\text { identification }^{b}\end{array}$} & \multirow{2}{*}{$\begin{array}{l}\text { Burnup }^{c} \\
\text { (FIMA) }\end{array}$} & \multirow{2}{*}{$\begin{array}{l}\text { Fast fluence }^{c} \\
(\mathrm{E}>0.18 \mathrm{MeV})\end{array}$} & \multicolumn{3}{|c|}{ Irradiation temperature $^{d}$} \\
\hline & & & & & TAVA & $\mathrm{TA}_{\min }$ & $\mathrm{TA}_{\max }$ \\
\hline $5-1-1$ & $\mathrm{UCO}$ & LEU09-OP2-Z141 & $12.80 \%$ & $3.41 \times 10^{25} \mathrm{n} / \mathrm{m}^{2}$ & $1,108^{\circ} \mathrm{C}$ & $956^{\circ} \mathrm{C}$ & $1,202^{\circ} \mathrm{C}$ \\
\hline $5-1-2$ & $\mathrm{UCO}$ & LEU09-OP2-Z154 & $12.88 \%$ & $3.42 \times 10^{25} \mathrm{n} / \mathrm{m}^{2}$ & $1,109^{\circ} \mathrm{C}$ & $962^{\circ} \mathrm{C}$ & $1,203^{\circ} \mathrm{C}$ \\
\hline $5-3-1$ & $\mathrm{UCO}$ & LEU09-OP2-Z132 & $12.03 \%$ & $3.28 \times 10^{25} \mathrm{n} / \mathrm{m}^{2}$ & $1,126^{\circ} \mathrm{C}$ & $1,016^{\circ} \mathrm{C}$ & $1,197^{\circ} \mathrm{C}$ \\
\hline
\end{tabular}

${ }^{a}$ The X-Y-Z compact numbering convention denotes the compact's location in the irradiation test train: capsule-level-stack.

${ }^{b}$ Physical properties data for individual compacts are available and referenced by fabrication identification number (Hunn, Montgomery, and Pappano 2010a, 60-69).

${ }^{c}$ Burnup (Sterbentz 2014, Table 6) and fast fluence (Sterbentz 2014, Table 12) are based on physics calculations.

${ }^{d}$ TAVA temperature, $\mathrm{TA}_{\min }$ temperature, and TA $\mathrm{max}_{\max }$ temperature are based on thermal calculations (Hawkes 2014, Table 3).

The transient temperature profile used for the safety testing of AGR-2 Compacts 5-1-1, 5-1-2, and 5-3-1 was essentially the same as a transient temperature profile used to safety test an irradiated $\mathrm{UO}_{2}$ fuel pebble from the Arbeitsgemeinschaft Versuchsreaktor (AVR) in the Federal Republic of Germany (Schenk, Pitzer, and Knauf 1993). The safety test temperature profile for Pebble AVR-91/31 was based on the shape of a calculated temperature profile for a depressurized core-conduction cooldown event that was modified to raise the peak temperature from the $1,600^{\circ} \mathrm{C}$ design basis to $1,695^{\circ} \mathrm{C}$. Three AGR-1 UCO fuel compacts were previously safety tested at Idaho National Laboratory (INL) using this temperature profile (Stempien et al. 2016). As summarized in the 2016 paper by Stempien et al., the transient temperature safety test of AVR-91/31 resulted in a significantly higher fraction of TRISO failure compared with $1,700^{\circ} \mathrm{C}$ isothermal tests of similar irradiated German fuel pebbles. This generated questions regarding whether fuel failure fractions determined using isothermal safety testing underpredict the fuel failure under more relevant transient temperature conditions. Based on AGR safety test observations to date (Demkowicz et al. 2015, Hunn et al. 2018b), it is more likely that the isothermal safety testing overpredicts fuel failure during a depressurization event because compacts are held longer at the peak temperature and chemical reactions are driving the observed fuel failure. The primary motivation for the two AGR program transient tests were to help address this uncertainty. 


\section{SAFETY TESTING METHOD}

The transient temperature safety test of AGR-2 Compacts 5-1-1, 5-1-2, and 5-3-1 used the same equipment and followed the same general safety testing method developed for AGR-1 safety testing in the CCCTF furnace (Baldwin et al. 2012), which was also used throughout the isothermal testing of AGR-2 compacts (Morris et al. 2014, Hunn et al. 2018b). To accommodate simultaneous testing of three compacts, a new holder was designed. Figure 2-1 shows the original one-compact holder and the new three-compact holder. Compared with the original one-compact holder, the three-compact holder uses three of the same screw-in lids to retain the compacts, has the same overall height, and the same dimensions for the thermocouple well. The only substantive change was enlarging the top section to accommodate three compacts.

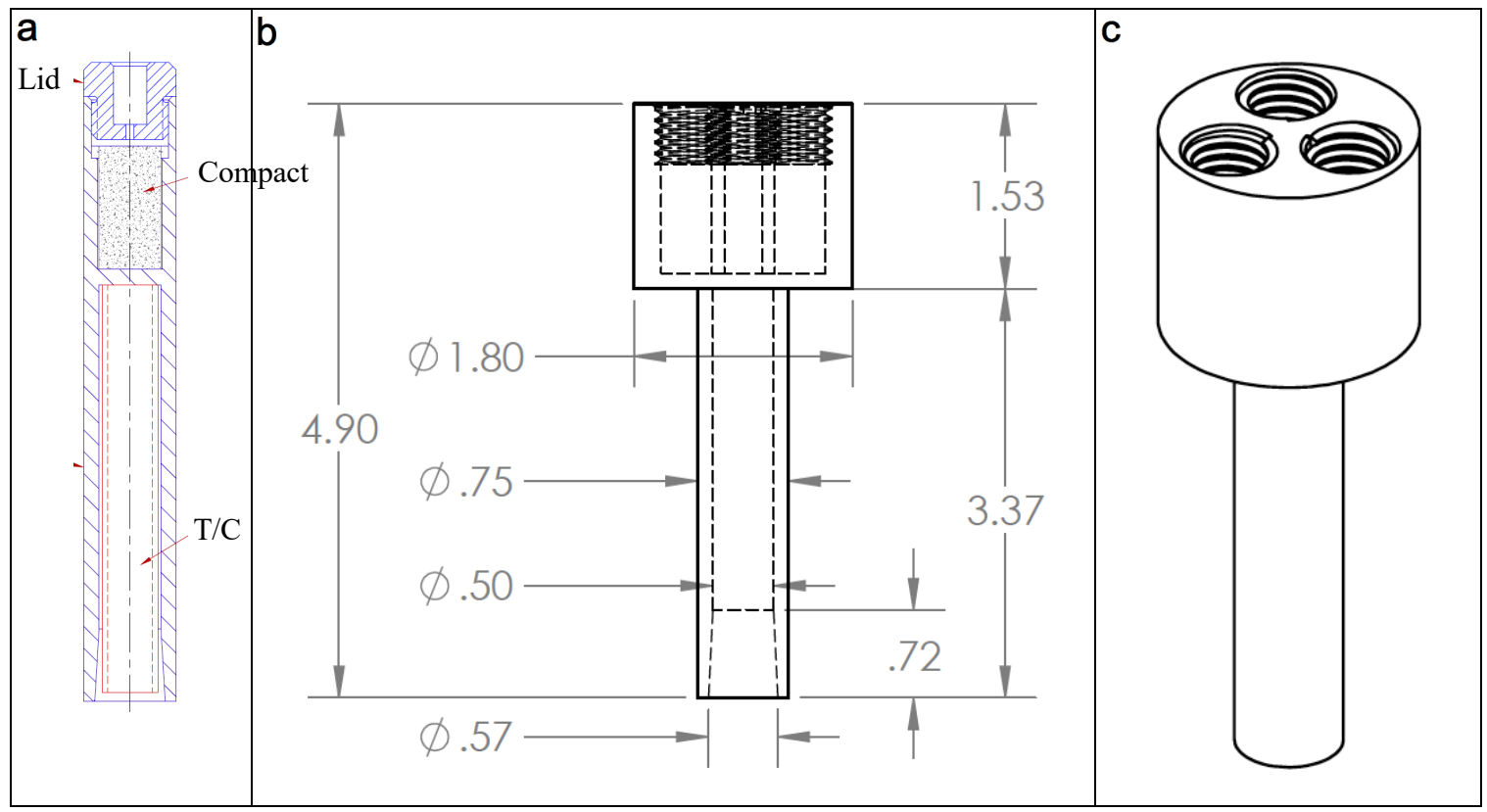

Figure 2-1. CCCTF graphite holders: (a) one-compact holder,

(b) three-compact holder with dimensions, and (c) three-compact holder.

The control setpoints and planned temperature profile for the transient temperature safety test of AGR-2 Compacts 5-1-1, 5-1-2, and 5-3-1 are shown in Table 2-1 and Figure 2-2, respectively. The initial 22-h hold at $300^{\circ} \mathrm{C}$ was to drive off any retained moisture; the AGR-1 and AGR-2 isothermal safety tests included a hold at $400^{\circ} \mathrm{C}$ for the same purpose. The 72 -h hold at $857^{\circ} \mathrm{C}$ was designed to mimic normal reactor operation. For AGR-1 and AGR-2 isothermal safety tests, this "operation temperature" hold was at a higher temperature of $1,250^{\circ} \mathrm{C}$. These two temperatures differ because the $857^{\circ} \mathrm{C}$ hold was based on a pebble-bed reactor design with $\mathrm{UO}_{2}$ fuel, while the $1,250^{\circ} \mathrm{C}$ hold was based on a prismatic-block reactor design with UCO fuel. As previously mentioned, the transient temperature portion of the test profile that began at $857^{\circ} \mathrm{C}$ and peaked at $1,695^{\circ} \mathrm{C}$ was designed to mimic the slow heat-up and cooldown that would occur in a helium-cooled graphite reactor if the helium cooling circuit failed, with the caveat that the peak temperature of $1,695^{\circ} \mathrm{C}$ was intentionally elevated about $100^{\circ} \mathrm{C}$ above the expected peak temperature during a depressurized core-conduction cooldown event. 
Table 2-1. Temperature setpoints used for safety testing of Compacts 5-1-1, 5-1-2, and 5-3-1

\begin{tabular}{crcc}
\hline Ramp time & Start temperature & End temperature & Hold time \\
\hline $0.5 \mathrm{~h}$ & $30^{\circ} \mathrm{C}^{a}$ & $300^{\circ} \mathrm{C}$ & $22 \mathrm{~h}$ \\
$1.5 \mathrm{~h}$ & $300^{\circ} \mathrm{C}$ & $857^{\circ} \mathrm{C}$ & $70 \mathrm{~h}$ \\
$3.7 \mathrm{~h}$ & $857^{\circ} \mathrm{C}$ & $1300^{\circ} \mathrm{C}$ & $0.1 \mathrm{~h}$ \\
$6.6 \mathrm{~h}$ & $1,300^{\circ} \mathrm{C}$ & $1585^{\circ} \mathrm{C}$ & $0.1 \mathrm{~h}$ \\
$7.4 \mathrm{~h}$ & $1,585^{\circ} \mathrm{C}$ & $1670^{\circ} \mathrm{C}$ & $0.1 \mathrm{~h}$ \\
$11.9 \mathrm{~h}$ & $1,670^{\circ} \mathrm{C}$ & $1695^{\circ} \mathrm{C}$ & $0.1 \mathrm{~h}$ \\
$11.9 \mathrm{~h}$ & $1,695^{\circ} \mathrm{C}$ & $1680^{\circ} \mathrm{C}$ & $0.1 \mathrm{~h}$ \\
$157.9 \mathrm{~h}$ & $1,680^{\circ} \mathrm{C}$ & $1342^{\circ} \mathrm{C}$ & $0.1 \mathrm{~h}$ \\
$99.9 \mathrm{~h}$ & $1,342^{\circ} \mathrm{C}$ & $1200^{\circ} \mathrm{C}$ & $0.1 \mathrm{~h}$ \\
$2 \mathrm{~h}$ & $1,200^{\circ} \mathrm{C}$ & $30^{\circ} \mathrm{C}^{a}$ & $10 \mathrm{~h}$ \\
\hline
\end{tabular}

${ }^{a}$ Run will start and end at ambient temperature.

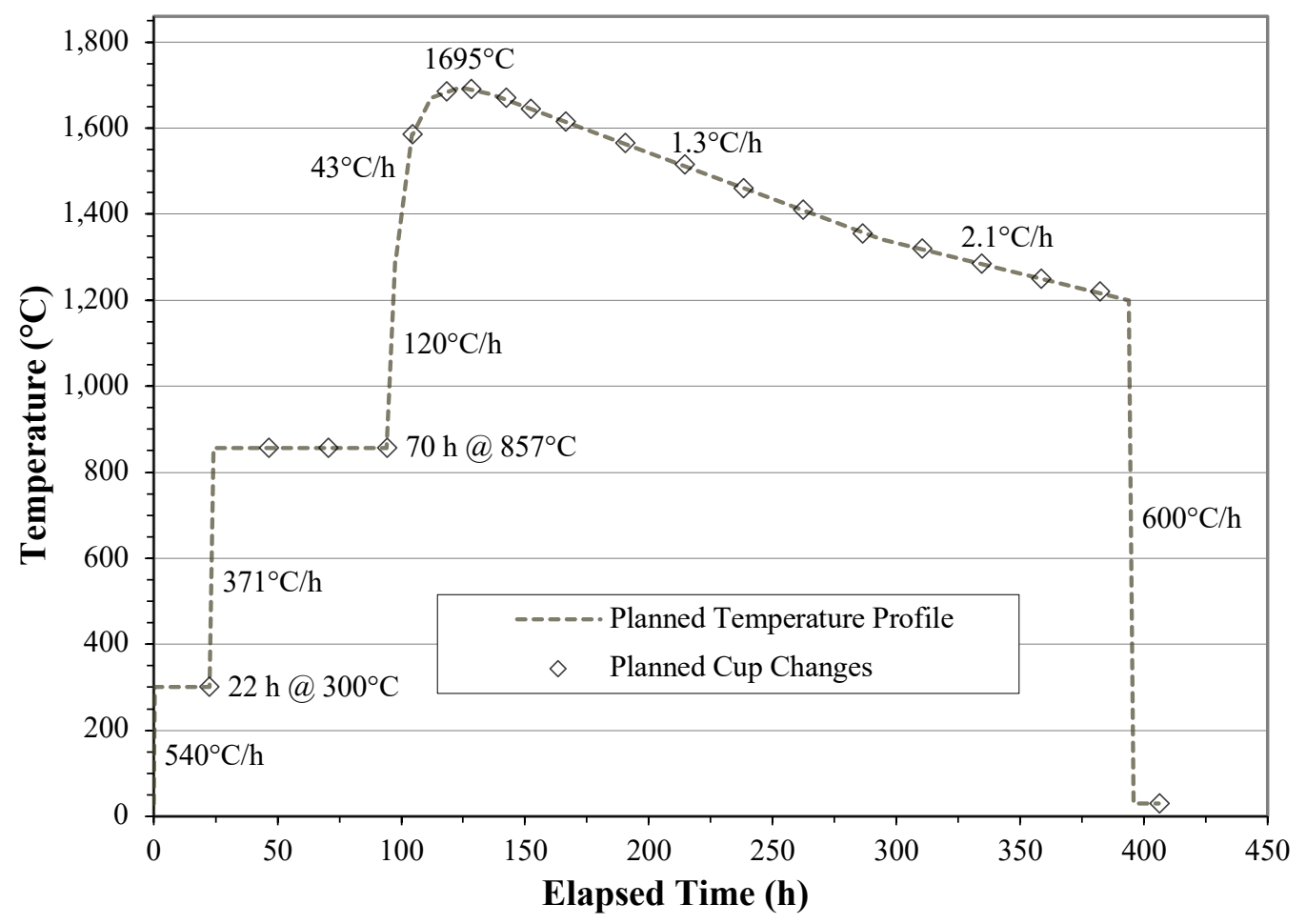

Figure 2-2. Transient temperature profile used for safety testing of Compacts 5-1-1, 5-1-2, and 5-3-1. 


\section{SAFETY TEST RESULTS}

Figure 3-1 shows the estimated time-dependent fractional release of ${ }^{85} \mathrm{Kr},{ }^{110 \mathrm{~m}} \mathrm{Ag},{ }^{134} \mathrm{Cs}$, and ${ }^{137} \mathrm{Cs}$ from Compacts 5-1-1, 5-1-2, and 5-3-1 during the transient temperature safety test. There were two deviations from the planned transient temperature test profile shown in Figure 2-2. The first deviation was near the beginning of the test. A small water leak was noted at the end of the $22-\mathrm{h}$ hold at $300^{\circ} \mathrm{C}$. The test was halted, and the furnace was returned to room temperature. The deposition cup was removed, and the fuel was returned to the shielded transfer cask to allow entry into the CCCTF modular hot cell and repair of the leaking coupling. After about $72 \mathrm{~h}$, the test was resumed from the starting point. The second deviation was at the end of the test. During the exchange of the eighth cup after reaching peak temperature, with the furnace at $\sim 1,400^{\circ} \mathrm{C}$, a bracket securing the cold finger failed and the next cup could not be inserted. Therefore, the furnace was reprogrammed for a controlled ramp-down to room temperature at the $600^{\circ} \mathrm{C} / \mathrm{h}$ rate specified for the end of the test. After consultation with the ORNL and INL technical leads, it was decided that the primary objective of the safety test to monitor for particle failure during a temperature transient peaking near $1,700^{\circ} \mathrm{C}$ was complete and that the test should be ended.

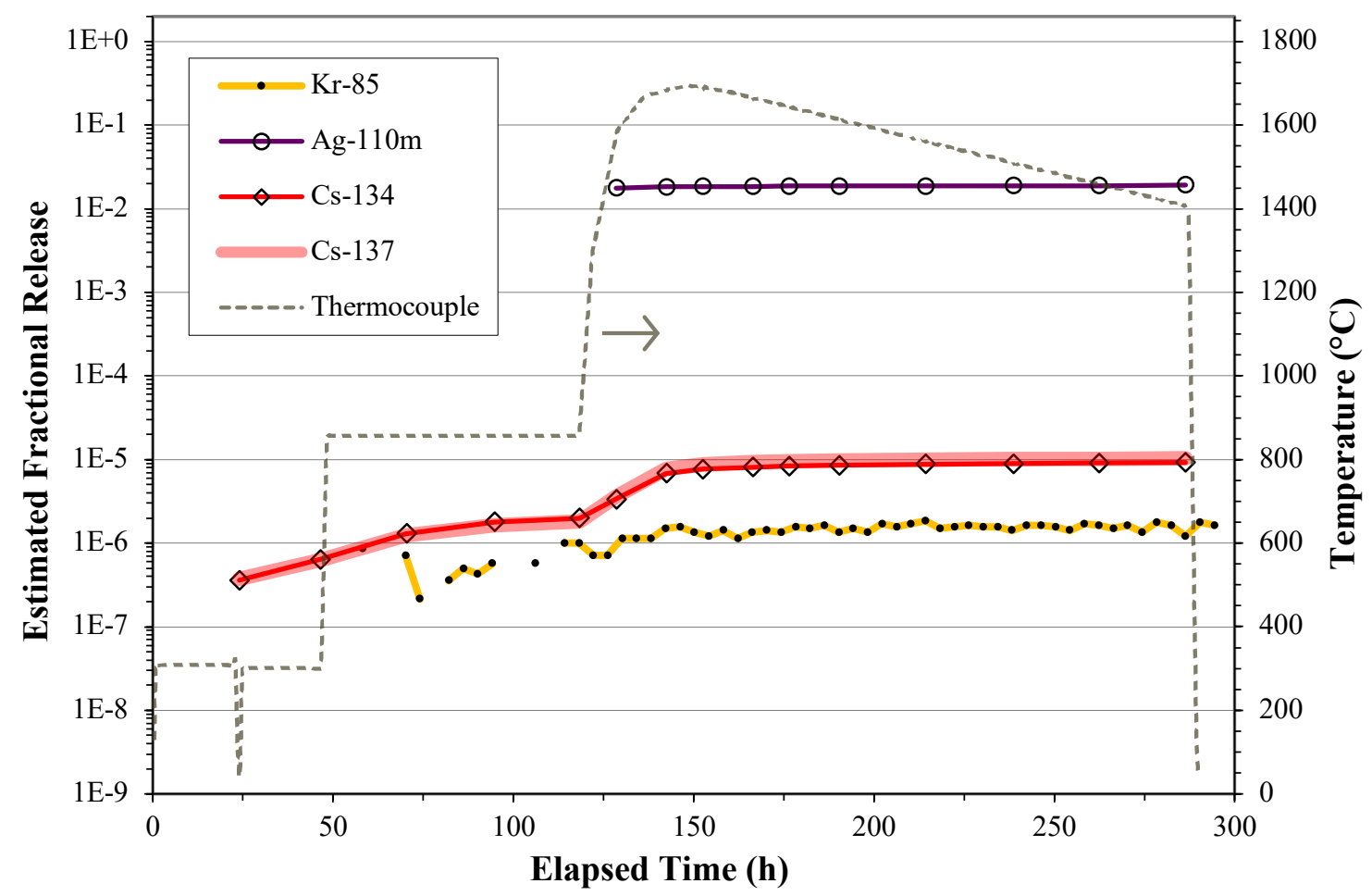

Figure 3-1. Fractional release during the transient temperature safety test (1E-4 is equivalent to the inventory in one particle).

The deposition cups and the removable tantalum components (the can that lines the CCCTF furnace and the gas inlet line) were gamma counted to obtain preliminary data on the fission product release from the compacts during the safety test. Average efficiencies for collection of silver and cesium on the deposition cups (Table 3-1) were estimated from the ratio of the cumulative activity on all the cups vs. the total activity measured on all the cups and the tantalum components. The fractional release values for silver and cesium plotted in Figure 3-1 are the decay-corrected activities on each cup divided by the collection efficiency and divided by the calculated inventory in the three compacts one day after the end of the irradiation (Sterbentz 2014). The fractional release values for ${ }^{85} \mathrm{Kr}$ come from a similar calculation applied to the cumulative activity in the liquid nitrogen-cooled traps in line with the sweep gas exhaust. 
Table 3-1. Activities and average collection efficiencies for silver and cesium

\begin{tabular}{lcccc}
\hline \multirow{2}{*}{ Isotope } & \multicolumn{2}{c}{ Cumulative decay-corrected activity $^{a}$} & \multirow{2}{*}{ Collection efficiency } \\
\cline { 2 - 4 } & Cups & Can & Line & \\
\hline${ }^{110 \mathrm{~m}} \mathrm{Ag}$ & $317 \mu \mathrm{Ci}$ & $4.88 \mu \mathrm{Ci}$ & $0 \mu \mathrm{Ci}$ & 0.985 \\
${ }^{134} \mathrm{Cs}$ & $10.2 \mu \mathrm{Ci}$ & $3.86 \mu \mathrm{Ci}$ & $0.496 \mu \mathrm{Ci}$ & 0.701 \\
${ }^{137} \mathrm{Cs}$ & $11.1 \mu \mathrm{Ci}$ & $3.13 \mu \mathrm{Ci}$ & $0.397 \mu \mathrm{Ci}$ & 0.758 \\
\hline
\end{tabular}

${ }^{a}$ Activity from preliminary gamma scans adjusted for decay to one day after end of irradiation (October 17, 2013).

Although some fission products may be retained in the graphite holder (Figure 2-1), retention of silver and cesium should be very low because these elements diffuse quickly through graphite above $1,400^{\circ} \mathrm{C}$. Therefore, the average collection efficiencies in Table 3-1 should be reasonable estimates of the actual collection efficiency on each cup. Europium release is not included in Figure 3-1 because the dominant fraction of what came out of the compact was probably retained in the graphite holder. There were traces of ${ }^{154} \mathrm{Eu}$ activity accumulated on the cups $(0.104 \mu \mathrm{Ci})$ and tantalum components $(0.179 \mu \mathrm{Ci})$. In total, this corresponded to $<5 \mathrm{E}-6$ of the compact inventory. It is likely that additional europium released during this test was sequestered in the graphite holder based on common observation of high retention of europium in the graphite holder at the end of CCCTF safety testing (Hunn et al. 2016). Collection efficiencies and fractional release values will be refined by post-safety-test analyses of the deposition cups, tantalum components, and graphite holder. These analyses will include leaching of the cups and tantalum components and burn-leaching of the graphite holder to reduce measurement uncertainty and allow for targeted analysis of ${ }^{90} \mathrm{Sr}$ (via beta spectroscopy) and stable isotopes (via mass spectroscopy).

\subsection{SILVER RELEASE DURING SAFETY TESTING}

There was no measurable ${ }^{110 \mathrm{~m}} \mathrm{Ag}$ detected on the first five deposition cups from the transient temperature safety test of Compacts 5-1-1, 5-1-2, and 5-3-1. These cups were resident in the CCCTF furnace during the holds at $300^{\circ} \mathrm{C}$ and $857^{\circ} \mathrm{C}$, with Cup 5 being removed at $895^{\circ} \mathrm{C}$ after the furnace had started ramping up after the $857^{\circ} \mathrm{C}$ hold. No measurable ${ }^{110 \mathrm{~m}} \mathrm{Ag}$ release should be expected below $895^{\circ} \mathrm{C}$ because it is below the melting point of silver $\left(962^{\circ} \mathrm{C}\right.$ ) and the vapor pressure is negligible at $\leq 0.1 \mathrm{~Pa}$ (Schadel and Birchenall 1950). For the AGR-1 and AGR-2 isothermal safety tests in the CCCTF, the first cup was removed near the end of the 12-h hold at $1,250^{\circ} \mathrm{C}$ (Morris et al. 2014). At this temperature, the vapor pressure of silver is $\sim 50 \mathrm{~Pa}$, which is sufficient to support transport of silver to the deposition cup.

Figure 3-1 shows that most of the silver that was released during the transient temperature safety test of Compacts 5-1-1, 5-1-2, and 5-3-1 was detected on Cup 6, which was removed at $1,584^{\circ} \mathrm{C}$ after a residence period of $10.0 \mathrm{~h}$. Cup 7 was removed at $1,684^{\circ} \mathrm{C}$ after a residence period of $13.7 \mathrm{~h}$; however, even with the higher temperature and longer residence time, the ${ }^{110 \mathrm{~m}} \mathrm{Ag}$ activity on Cup 7 was only $3.4 \%$ of the activity on Cup 6. This rapid release of silver during the ramp-up from $895^{\circ} \mathrm{C}$ to $1,684^{\circ} \mathrm{C}$ is consistent with results from isothermal safety testing of AGR compacts, where most of the silver that was released during irradiation and sequestered in the compact matrix and/or outer pyrolytic carbon (OPyC) coating layer was released as compacts were heated to safety test temperatures of $1,600^{\circ} \mathrm{C}$ or higher (Morris et al. 2014).

Figure 3-2 shows the average rate for ${ }^{110 \mathrm{~m}} \mathrm{Ag}$ collection during each cup residence period. After the initial collection of most of the silver sequestered in the compact matrix and/or OPyC on Cup 6, the rate dropped precipitously. There was a small increase in the release rate on the last two cups before the safety test was terminated. Cup 14 was in the furnace between $1,506^{\circ} \mathrm{C}$ and $1,459^{\circ} \mathrm{C}$. Cup 15 was in the furnace between $1,458^{\circ} \mathrm{C}$ and $1,406^{\circ} \mathrm{C}$. Indications of diffusive release of ${ }^{110 \mathrm{~m}} \mathrm{Ag}$ through intact $\mathrm{SiC}$ have been seen at $1,800^{\circ} \mathrm{C}$ but not at $1,600^{\circ} \mathrm{C}$ (Morris et al. 2014). There have also been observations that diffusive release of ${ }^{110 \mathrm{~m}} \mathrm{Ag}$ is higher between $1,075^{\circ} \mathrm{C}$ and $1,375^{\circ} \mathrm{C}$ than at $1,600^{\circ} \mathrm{C}$ (Hunn et al. 2015b). It could be that the slight increase observed on the last two cups was related to this lower temperature release. 


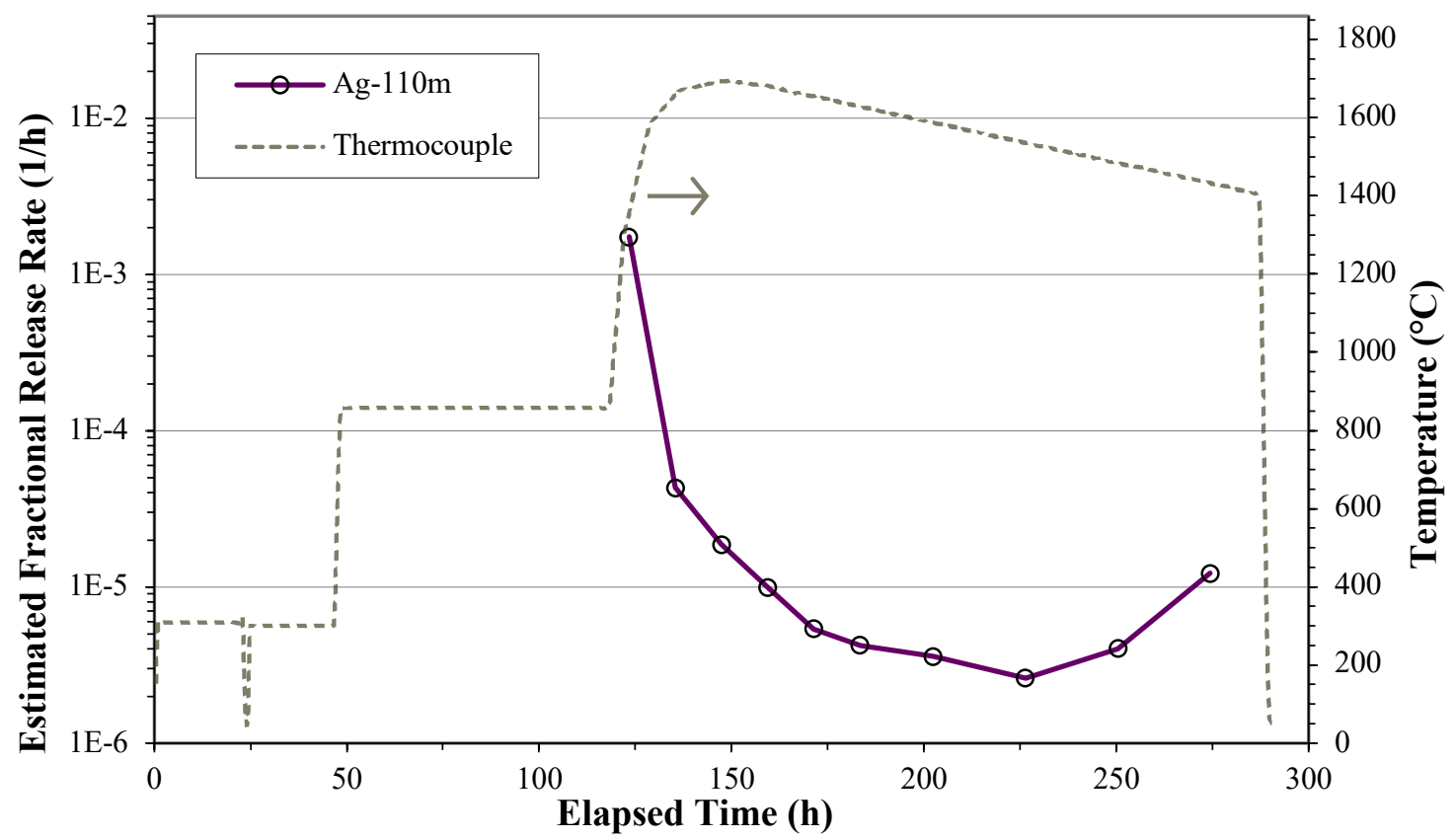

Figure 3-2. Rate of ${ }^{110 \mathrm{~m}} \mathrm{Ag}$ release during safety test of Compacts 5-1-1, 5-1-2, and 5-3-1.

\subsection{KRYPTON AND CESIUM RELEASE DURING SAFETY TESTING}

The cumulative fractional release of ${ }^{85} \mathrm{Kr}$ from Compacts 5-1-1, 5-1-2, and 5-3-1 at the end of the transient temperature safety test was $1.58 \mathrm{E}-6$. This corresponds to only $1.5 \%$ of one particle equivalent, so it most likely did not come from a particle with failed TRISO, which would result in the release of a significantly higher fraction of a particle's ${ }^{85} \mathrm{Kr}$ inventory. It is not unusual for some ${ }^{85} \mathrm{Kr}$ to be released during safety testing in the absence of particle failure. None of the six AGR-2 compacts safety tested at $1,600^{\circ} \mathrm{C}$ exhibited TRISO or SiC failure, and three out the six had measurable amounts of ${ }^{85} \mathrm{Kr}$ detected in the sweep gas (Table 3-2). Compact 6-4-3, the one $1800^{\circ} \mathrm{C}$ safety test with no failed $\mathrm{SiC}$ particles, also exhibited measurable ${ }^{85} \mathrm{Kr}$ release during safety testing. Krypton release not associated with particle failure might come from uranium contamination outside the $\mathrm{SiC}$ in as-fabricated compacts, which was present in the AGR-2 UCO compacts with an average compact fraction of 3.94E-6 (Hunn, Savage, and Silva 2010).

Table 3-2. Minor release of ${ }^{85} \mathrm{Kr}$ and ${ }^{134} \mathrm{Cs}$ from AGR-2 UCO compacts with no failed particles

\begin{tabular}{lcccc}
\hline AGR-2 Compact & $\begin{array}{c}\text { Irradiation temperature } \\
\text { TAVA }\end{array}$ & $\begin{array}{c}\text { Safety test } \\
\text { temperature }\end{array}$ & ${ }^{85} \mathrm{Kr}$ & ${ }^{134} \mathrm{Cs}$ \\
\hline $2-2-2$ & $1,287^{\circ} \mathrm{C}$ & $1,600^{\circ} \mathrm{C}$ & $5.4 \mathrm{E}-6(0.017)$ & $2.5 \mathrm{E}-7(0.0008)$ \\
$2-3-1$ & $1,296^{\circ} \mathrm{C}$ & $1,600^{\circ} \mathrm{C}$ & $<7 \mathrm{E}-7(<0.002)$ & $3.96 \mathrm{E}-6(0.013)$ \\
$5-2-1$ & $1,141^{\circ} \mathrm{C}$ & $1,600^{\circ} \mathrm{C}$ & $7.51 \mathrm{E}-6(0.024)$ & $4.20 \mathrm{E}-6(0.013)$ \\
$5-2-2$ & $1,141^{\circ} \mathrm{C}$ & $1,600^{\circ} \mathrm{C}$ & $<7 \mathrm{E}-7(<0.002)$ & $5.91 \mathrm{E}-6(0.019)$ \\
$6-2-2$ & $1,129^{\circ} \mathrm{C}$ & $1,600^{\circ} \mathrm{C}$ & $4.58 \mathrm{E}-6(0.015)$ & $7.67 \mathrm{E}-6(0.024)$ \\
$6-4-2$ & $1,018^{\circ} \mathrm{C}$ & $1,600^{\circ} \mathrm{C}$ & $<9 \mathrm{E}-7(<0.003)$ & $6.20 \mathrm{E}-5(0.20)^{a}$ \\
$6-4-3$ & $987^{\circ} \mathrm{C}$ & $1,800^{\circ} \mathrm{C}$ & $5.03 \mathrm{E}-6(0.016)$ & $1.97 \mathrm{E}-5(0.063)^{a}$ \\
$5-1-1,5-1-2,5-3-1$ & $1,108-1126^{\circ} \mathrm{C}$ & up to $1,695^{\circ} \mathrm{C}$ & $1.58 \mathrm{E}-6(0.015)$ & $\sim 9.2 \mathrm{E}-6(\sim 0.09)$ \\
\hline
\end{tabular}

Note: Values are reported as compact inventory fraction and particle inventory fraction (in parentheses).

${ }^{a}$ Most of the cesium release from Compact 6-4-2 and about half of the cesium release from Compact 6-4-3 was from cross contamination from previous safety tests of compacts with $\mathrm{UO}_{2}$ fuel that had high cesium release (Hunn et al. 2019a). 
The cumulative fractional release of ${ }^{134} \mathrm{Cs}$ from Compacts 5-1-1, 5-1-2, and 5-3-1 at the end of the transient temperature safety test was $\sim 9.3 \mathrm{E}-6$. This is a little higher than the ${ }^{134} \mathrm{Cs}$ release during $1,600{ }^{\circ} \mathrm{C}$ safety testing of Compacts 5-2-1, 5-2-2, and 6-2-2, which ranged from 4.2E-6 to 7.7E-6 (Table 3-2), but is nevertheless low enough to attribute to sources not related to cesium release through failed SiC. These sources could include (1) contamination picked up in the hot cell during handling of the graphite holder, (2) contamination on internal CCCTF components from previous tests, and (3) low levels of cesium sequestered in the compact matrix and/or OPyC at the end of irradiation. Compacts 2-2-2 and 2-3-1 are not included in this comparison because the relatively lower ${ }^{134} \mathrm{Cs}$ release during safety testing could be related to their higher irradiation temperature resulting in less cesium sequestered in the matrix and/or $\mathrm{OPyC}$ at the end of the irradiation. Compact 6-4-2 is not included in this comparison because the measured ${ }^{134} \mathrm{Cs}$ release was dominated by release of contamination in the CCCTF from the previous $1,700^{\circ} \mathrm{C}$ safety test of AGR-2 $\mathrm{UO}_{2}$ Compact 3-4-1, which resulted in very high cesium release. This determination of cross contamination was made based on the fact that the ${ }^{134} \mathrm{Cs} /{ }^{137} \mathrm{Cs}$ ratio on the cups from the Compact 6-4-2 safety test clearly matched the expected ratio for Compact 3-4-1 rather than Compact 6-4-2 (Hunn et al. 2019a, p. 8). The cumulative ${ }^{134} \mathrm{Cs}$ release from Compacts 5-1-1, 5-1-2, and 5-3-1 during the transient temperature safety test was similar to the estimated actual ${ }^{134} \mathrm{Cs}$ release from Compact 6-4-3 during safety testing at $1,800^{\circ} \mathrm{C}$, which was about half of the value reported for Compact 6-4-3 in Table 3-2. The other half of what was measured on the Compact 6-4-3 safety test deposition cups appeared to be from release of contamination in the CCCTF from previous AGR-2 $\mathrm{UO}_{2}$ compact safety tests, based on the observed ${ }^{134} \mathrm{Cs} /{ }^{137} \mathrm{Cs}$ ratio on individual cups (Hunn et al. 2019a, p. 8).

The time dependence of the cesium release supports a conclusion that it more likely came from the compact matrix and/or OPyC than from a particle with failed SiC. Figure 3-3 shows the average rate that ${ }^{134} \mathrm{Cs}$ and ${ }^{137} \mathrm{Cs}$ were collected during each cup residence period. There was a small increase in the cesium release rate during the ramp-up to $857^{\circ} \mathrm{C}$ (Cup 3), followed by a decrease in release rate during the $857^{\circ} \mathrm{C}$ hold. There was a larger increase in the cesium release rate during the ramp-up from $857^{\circ} \mathrm{C}$ to $1,684^{\circ} \mathrm{C}$ (Cup 6 and Cup 7), but the average cesium release rate measured on Cup 8 was only one-third the rate measured on Cup 7. Cup 8 was in the furnace for the 10-h period when the compacts went through the peak of the transient temperature profile - from $1,684^{\circ} \mathrm{C}$ up to $1,695^{\circ} \mathrm{C}$ and down to $1,689^{\circ} \mathrm{C}$. If the rate increase observed on Cup 6 and Cup 7 were from cesium diffusing through degraded $\mathrm{SiC}$, the release rate should have continued to increase as the temperature was raised above $1,684^{\circ} \mathrm{C}$, given that the cumulative release before Cup 8 was only about $7 \%$ of one particle equivalent.

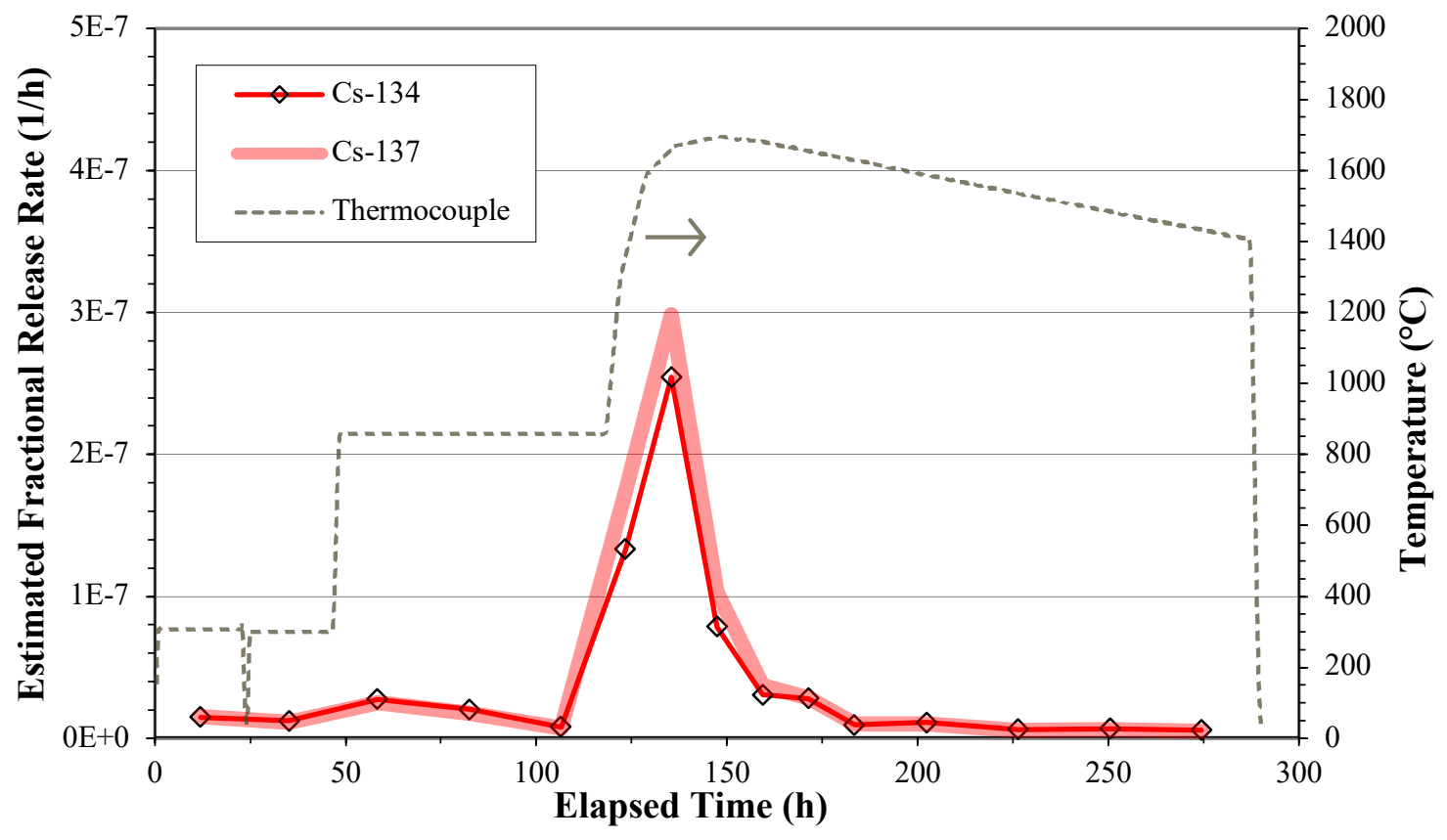

Figure 3-3. Rate of cesium release during the safety test of Compacts 5-1-1, 5-1-2, and 5-3-1. 
Destructive examination after safety testing may not provide additional data to support or contradict the conclusion that no particles had failed SiC. If all of the observed cesium collected in the CCCTF during the transient temperature safety test came from a single failed particle, it would equate to about $9-10 \%$ of the particle's cesium inventory. A particle with 9-10\% cesium loss would most likely not be identified with the Irradiated Microsphere Gamma Analyzer because it would likely have a ${ }^{137} \mathrm{Cs}$ activity within the bounds of the distribution of measured activity in the other particles, which ranged from $85-125 \%$ for recently analyzed Compact 5-2-1. Compact deconsolidation and leach-burn-leach analysis (DLBL) could possibly confirm the absence of any particles with failed $\mathrm{SiC}$ by showing negligible exposed uranium, if no particles are damaged during the DLBL process. However, out of the seven AGR-2 compacts without apparent $\mathrm{SiC}$ failures after isothermal safety testing (Table 3-2), particle damage during DLBL occurred in three. Therefore, it is likely that the DLBL of Compacts 5-1-1, 5-1-2, and 5-3-1 would be compromised by particle damage and that the results would be inconclusive with regard to the possible presence of one failed particle. 


\section{CONCLUSIONS}

AGR-2 UCO Compacts 5-1-1, 5-1-2, and 5-3-1 were simultaneously subjected to a transient temperature safety test with a peak temperature of $1,695^{\circ} \mathrm{C}$. The cumulative release of ${ }^{85} \mathrm{Kr}$ was equivalent to $1.5 \%$ of the average ${ }^{85} \mathrm{Kr}$ inventory in one particle, which indicates that there were no exposed kernels in any of the three compacts, either from as-fabricated defects in the TRISO coating or from failure of the TRISO integrity as a result of the safety testing. The cumulative releases of ${ }^{134} \mathrm{Cs}$ and ${ }^{137} \mathrm{Cs}$ were less than $10 \%$ of one particle equivalent. This is slightly higher than what has been observed for $1,600^{\circ} \mathrm{C}$ isothermal safety tests on single AGR-2 compacts. However, it is significantly lower than what has been observed to be released when single particles exhibited $\mathrm{SiC}$ failure during $1,600^{\circ} \mathrm{C}$ safety testing of three AGR-1 compacts, where ${ }^{134} \mathrm{Cs}$ release ranged from $49-89 \%$ (Hunn et al. 2014). The low cumulative cesium release and the drop off of the cesium release rate before reaching the maximum test temperature supports a conclusion that there was no $\mathrm{SiC}$ failure during the transient temperature safety testing of Compacts 5-1-1, 5-1-2, and 5-3-1.

The time-dependent release of cesium during the transient temperature safety testing of AGR-2 UCO Compacts 5-1-1, 5-1-2, and 5-3-1 was qualitatively similar to that observed during the transient temperature safety testing of AGR-1 UCO Compacts 1-4-2, 1-1-3, and 1-1-1 (Stempien et al. 2018). In both tests, a minor fraction of the total cesium release was detected on the first cup after the ramp-up to $857^{\circ} \mathrm{C}$ with little cesium released over the remainder of the $857^{\circ} \mathrm{C}$. In both tests, the cesium release rate increased most dramatically during the ramp-up from $857^{\circ} \mathrm{C}$, but the rate peaked in both tests before reaching the $1,695^{\circ} \mathrm{C}$ maximum test temperature. This suggests that the cesium sequestered in the matrix and/or OPyC of the compacts was depleted before reaching $1,695^{\circ} \mathrm{C}$ in both tests. The fractional release of cesium in the transient temperature safety testing of AGR-1 UCO Compacts 1-4-2, 1-1-3, and 1-1-1 was $4.8 \mathrm{E}-7$, which is significantly less than the $\sim 9.2 \mathrm{E}-6$ compact fraction released from the AGR-2 compacts. This difference is likely related to the fact that the average as-fabricated uranium contamination fraction outside of intact $\mathrm{SiC}$ in the AGR-1 Variant 3 compacts used for the AGR-1 transient test was 1.62E-7 (Hunn et al. 2006), compared with 3.94E-6 for the AGR-2 UCO compacts.

The combined results of transient temperature safety testing of three AGR-1 UCO compacts and three AGR-2 UCO compacts show that transient temperature safety testing did not result in significantly different fission product retention compared with isothermal testing in a similar temperature range. There were no indications of the higher TRISO failure rates like those observed in the transient temperature test of German $\mathrm{UO}_{2}$ pebble AVR-91/31 as reported in Schenk, Pitzer, and Knauf (1993). 


\section{REFERENCES}

Baldwin, C. A., J. D. Hunn, R. N. Morris, F. C. Montgomery, C. M. Silva, and P. A. Demkowicz. 2012. "First Elevated Temperature Performance Testing of Coated Particle Fuel Compacts from the AGR-1 Irradiation Experiment." Paper HTR2012-3-027. Proc. 6th International Topical Meeting on High Temperature Reactor Technology (HTR-2012), Tokyo, Japan, October 28-November 1, 2012. Also published in Nucl. Eng. Des. 271: 131-141.

Barnes, C. M., and D. W. Marshall. 2009. FY 2009 Particle Fabrication and Coater Test Report. INL/EXT-09-16545, Revision 0. Idaho Falls, ID: Idaho National Laboratory.

Collin, B. P. 2014. AGR-2 Irradiation Test Final As-Run Report. INL/EXT-14-32277, Revision 2. Idaho Falls, ID: Idaho National Laboratory.

Demkowicz, P. A. 2013. AGR-2 Post Irradiation Examination Plan. PLN-4616, Revision 0. Idaho Falls, ID: Idaho National Laboratory.

Demkowicz, P. A., J. D. Hunn, R. N. Morris, I. J. van Rooyen, T. J. Gerczak, J. M. Harp, and S. A. Ploger. 2015. AGR-1 Post Irradiation Examination Final Report. INL/EXT-15-36407, Revision 0. Idaho Falls, ID: Idaho National Laboratory.

Hawkes, G. L. 2014. AGR-2 Daily As-Run Thermal Analyses. INL/ECAR-2476, Revision 1. Idaho Falls, ID: Idaho National Laboratory.

Hunn, J. D., F. C. Montgomery, and P. J. Pappano. 2006. Data Compilation for AGR-1 Variant 3 Compact Lot LEU01-49T-Z. ORNL/TM-2006/510, Revision 0. Oak Ridge, TN: Oak Ridge National Laboratory.

Hunn, J. D. 2010. AGR-2 Fuel Compacts Information Summary: Prepared for the NRC MELCOR Project. ORNL/TM-2010/296, Revision 1. Oak Ridge, TN: Oak Ridge National Laboratory.

Hunn, J. D., F. C. Montgomery, and P. J. Pappano. 2010a. Data Compilation for AGR-2 UCO Variant Compact Lot LEU09-OP2-Z. ORNL/TM-2010/017, Revision 1. Oak Ridge, TN: Oak Ridge National Laboratory.

Hunn, J. D., F. C. Montgomery, and P. J. Pappano. 2010b. Data Compilation for AGR-2 $\mathrm{UO}_{2}$ Compact Lot LEU11-OP2-Z. ORNL/TM-2010/055, Revision 1. Oak Ridge, TN: Oak Ridge National Laboratory.

Hunn, J. D., T. W. Savage, and C. M. Silva. 2010. AGR-2 Fuel Compact Pre-Irradiation Characterization Summary Report. ORNL/TM-2010/226, Revision 0. Oak Ridge, TN: Oak Ridge National Laboratory.

Hunn, J. D., C. A. Baldwin, T. J. Gerczak, F. C. Montgomery, R. N. Morris, C. M. Silva, P. A. Demkowicz, J. M. Harp, S. A. Ploger, I. J. van Rooyen, and K. E. Wright. 2014. "Detection and Analysis of Particles with Failed SiC in AGR-1 Fuel Compacts." Paper HTR2014-31254. Proc. 7th International Topical Meeting on High Temperature Reactor Technology (HTR-2014), Weihai, China, October 27-31, 2014. Also published in Nucl. Eng. Des. 360: 36-46.

Hunn, J. D., R. N. Morris, C. A. Baldwin, and F. C. Montgomery. 2015a. Safety-Testing of AGR-2 UO Compacts 3-3-2 and 3-4-2. ORNL/TM-2015/388, Revision 0. Oak Ridge, TN: Oak Ridge National Laboratory.

Hunn, J. D., R. N. Morris, C. A. Baldwin, F. C. Montgomery, and T. J. Gerczak. 2015b. PIE on Safety Tested AGR-1 Compact 4-2-2. ORNL/TM-2015/033, Revision 0. Oak Ridge, TN: Oak Ridge National Laboratory.

Hunn, J. D., R. N. Morris, C. A. Baldwin, and F. C. Montgomery. 2016. Safety-Testing of AGR-2 UCO Compacts 5-2-2, 2-2-2, and 5-4-1. ORNL/TM-2016/423, Revision 1. Oak Ridge, TN: Oak Ridge National Laboratory. 
Hunn, J. D., R. N. Morris, C. A. Baldwin, Z. M. Burns, F. C. Montgomery, and D. J. Skitt. 2017. SafetyTesting of AGR-2 UCO Compacts 6-4-2 and 2-3-1. ORNL/TM-2017/439, Revision 0. Oak Ridge, TN: Oak Ridge National Laboratory.

Hunn, J. D., R. N. Morris, F. C. Montgomery, T. J. Gerczak, D. J. Skitt, G. W. Helmreich, B. D. Eckhart, and Z. M. Burns. 2018a. Safety-Testing and Post-Safety-Test Examination of AGR-2 UCO Compact 2-3-2 and AGR-2 UO 2 Compact 3-4-1. ORNL/TM-2018/956, Revision 0. Oak Ridge, TN: Oak Ridge National Laboratory.

Hunn, J. D., R. N. Morris, F. C. Montgomery, T. J. Gerczak, D. J. Skitt, C. A. Baldwin, J. A. Dyer, G. W. Helmreich, B. D. Eckhart, Z. M. Burns, P. A. Demkowicz, and J. D. Stempien. 2018b. "PostIrradiation Examination and Safety Testing of US AGR-2 Irradiation Test Compacts." Paper HTR2018-0010. Proc. 9th International Topical Meeting on High Temperature Reactor Technology (HTR-2018), Warsaw, Poland, October 8-10, 2018.

Hunn, J. D., T. J. Gerczak, R. N. Morris, F. C. Montgomery, D. J. Skitt, B. D. Eckhart, and Z. M. Burns. 2019a. Safety-Testing and Destructive Examination of AGR-2 UCO Compact 2-1-2. ORNL/TM2019/1201, Revision 0. Oak Ridge, TN: Oak Ridge National Laboratory.

Hunn, J. D., T. J. Gerczak, R. N. Morris, F. C. Montgomery, D. J. Skitt, B. D. Eckhart, and Z. M. Burns. 2019b. Safety-Testing and Destructive Examination of AGR-2 UCO Compact 6-4-3. ORNL/TM2019/1200, Revision 0. Oak Ridge, TN: Oak Ridge National Laboratory.

Morris, R. N., P. A. Demkowicz, J. D. Hunn, C. A. Baldwin, and E. L. Reber. 2014. "Performance of AGR-1 High Temperature Reactor Fuel During Post-Irradiation Heating Tests." Paper HTR201431135. Proc. 7th International Topical Meeting on High Temperature Reactor Technology (HTR2014), Weihai, China, October 27-31, 2014. Also published in Nucl. Eng. Des. 306: 24-35.

Schadel, H. M., and C. E. Birchenall. 1950. "The Vapor Pressure of Silver.” JOM 2(9): 1134-1138.

Schenk, W., D. Pitzer, and H. Knauf. 1993. Simulation der max. MODUL-Störfallaufheizkurve (AVRGLE 3, 09/20) und deren Extrapolation auf $1700^{\circ} \mathrm{C}$ (AVR-GLE 3, 91/31), IWE-TN-17/93 Forschungszentrum Jülich GmbH (KFA).

Stempien, J. D., P. A. Demkowicz, E. L. Reber, and C. L. Christensen. 2016. "High-Temperature Safety Testing of Irradiated AGR-1 TRISO Fuel." Paper HTR2016-18595. Proc. 8th International Topical Meeting on High Temperature Reactor Technology (HTR-2016), Las Vegas, Nevada, November 6$10,2016$.

Sterbentz, J. W. 2014. JMOCUP As-Run Daily Depletion Calculation for the AGR-2 Experiment in the ATR B-12 Position. ECAR-2066, Revision 2. Idaho Falls, ID: Idaho National Laboratory. 